\title{
Spørgetid
}

\section{Kritisk dialog med Kina?}

Spm. nr. S 1080

Spørgsmål til videnskabsministeren af Benny Engelbrecht (S): "Hvorfor undlod ministeren at omtale Kinas forhold til menneskerettigheder kritisk, da han i efteråret 2007 besøgte landet?"

Videnskabsministeren (Helge Sander): Ja, så skifter vi emne. Nu handler det om dialog om menneskerettigheder, som vi jo alle ved er en integreret del af Danmarks og EU's samarbejde med Kina med henblik på at støtte landets demokratiske udvikling og sikre beskyttelse af mindretal. Det vil der ikke blive ændret på.

Den løbende dialog med de kinesiske myndigheder om disse spørgsmål varetages fra dansk side af udenrigsministeren. Når det er sagt, mener jeg, at det er vigtigt, at den kritiske dialog føres på mange forskellige niveauer. Mit besøg hos den kinesiske videnskabsminister og undervisningsminister i september sidste år var det første møde, jeg havde med kineserne. Formålet var at opbygge relationer og indgå en række samarbejdsaftaler på forsknings- og uddannelsesområdet.

I et reelt og åbenhjertigt partner- skab vil der fremadrettet også være plads til dialog om vanskelige spørgsmål af mere principiel karakter. Inden for Videnskabsministeriets ressort er det problemstillinger vedrørende videnskabelig metode og forskningsfrihed, der især trænger sig på, og disse spørgsmål vil indgå i det videre samarbejde med Kina, når vi har fokus på forskning og uddannelse.

\section{Benny Engelbrecht:}

Indledningsvis vil jeg starte med at gratulere ministeren. Der er ingen tvivl om, at der efter ministerens besøg i Kina har været massivt fokus på det samarbejde, der er imellem Kina og Danmark. Der har været fremlagt mange særdeles interessante resultater, der er kommet nye tiltag og samarbejdsrelationer på mange forskellige måder, det kommer vi ikke uden om.

Det efterlader os jo så med det åbenlyse spørgsmål, om nogle af disse gode resultater, der er opnået, har været mere i fokus end det at føre en konkret kritisk dialog med Kina under ministerens besøg sidste år. Som det også er fremgået af dagspressen, har der ikke fundet en kritisk dialog sted under besøget i 
Kina - det går jeg ud fra at ministeren også kan bekræfte. Det kan man sige er ærgerligt. Det er også forunderligt, ikke mindst i betragtning af den store indsats og den store opmærksomhed, som netop Tibetspørgsmålet og hele det olympiske spørgsmål i den grad får i øjeblikket.

Spørgsmålet må derfor også være, om ministeren fremadrettet har tænkt sig at føre en kritisk dialog. For det er tydeligt, at ministeren har særdeles gode forbindelser og kontakter med Kina og med det politiske system i Kina. Det håber jeg at vi kan få bekræftet her i dag.

\section{Videnskabsministeren:}

Først og fremmest tak for de venlige bemærkninger.

For så vidt angår den kritiske dialog, vil jeg gerne som udgangspunkt sige, at jeg føler, det er utrolig afgørende, at vi har et tæt samarbejde med kineserne, at vi ikke sidder tilbage med korslagte arme og tror, det er den måde, vi påvirker tingene bedst på. Jeg mener rent faktisk, det bl.a. er ved hjælp af den strategi, som spørgeren også omtaler.

I den forbindelse vil jeg gerne gentage, hvad jeg har sagt flere gange, at den måde, hvorpå jeg føler at jeg kan yde et bidrag, er ved at fokusere på de områder, hvor der også er mangler i Kina i dag. Det drejer sig selvfølgelig om de videnskabelige metoder, forskningsfrihed og ophavsrettigheder. Det har vi gjort meget konkret, og som det fremgår af strategien, er det jo også noget, vi har fået skrevet ind i den. Derfor mener jeg i og for sig, at jeg har gjort det, som var særdeles relevant på det område, jeg repræsenterer.

\section{Kirsten Brosbøl (S):}

Men når det her spørgsmål er blevet ekstra relevant siden sidst, så er det jo også, fordi der er opstået en vis forvirring om regeringens holdning til, hvordan man skal forholde sig til de menneskerettighedskrænkelser, som alle jo ved foregår i Kina - der har jo senest i forbindelse med problemerne i Tibet været stor opmærksomhed om det.

Fra Socialdemokraternes side skal der ikke herske nogen tvivl om, at vi er meget optaget af, at regeringen også fører den kritiske dialog, som man tilkendegiver, at man vil gøre. Det er jo også sådan, at efter det kom frem, at videnskabsministeren havde været i Kina uden at påtale de her ting, så er videnskabsministeren jo også blevet sat på plads af statsministeren, som siger, at det selvfølgelig forventes, at man fører en kritisk dialog. Det fremgik af dagspressen, at statsministeren var ude og præcisere, at det selvfølgelig forventes, at fagministrene tager forhold vedrørende menneskerettigheder og demokrati op, når de er på besøg i Kina.

Så det er jo sådan lidt en zigzagkurs vi oplever fra regeringen: 
Først tager man ikke noget op, og så gør man det sandelig alligevel. Hvad er det egentlig helt konkret, regeringen vil med hensyn til den her kritiske dialog med Kina?

\section{Videnskabsministeren:}

Som jeg allerede næunte i min første besvarelse, så mener jeg, at det, for så vidt angår de overordnede forhold, er vigtigt, at det foregår gennem EU, og at det på nationalt plan er udenrigsministeren, der fører den overordnede kritiske linje overfor Kina.

Når jeg stiller mig uforstående over for, at jeg skulle være blevet sat på plads af statsministeren, så er det, fordi jeg netop som fagminister har anført de forhold, som er særdeles relevante inden for mit område, og som jeg også sagde i den foregående besvarelse, vil jeg gerne bede om, at man noterer sig, at det ikke bare er noget, der er blevet sagt, men at det også noget, som indgår i de aftaler, vi har med kineserne, og som fremgår af selve strategien, der ligger her. Så det vil jeg gerne fremover gøre, og jeg vil gerne understrege endnu engang, at jeg mener, at den måde, hvorpå vi allerbedst kan påvirke den udvikling, simpelt hen er ved, at vi er aktive, hver på vort område, og det er det, jeg har forsøgt at være med den dansk-kinesiske videnstrategi.

\section{Kirsten Brosbøl:}

Jo, men det kræver jo også, at man, når man rejser til Kina, tager nogle af de spørgsmål op, som kan være lidt ømfindtlige. Det jo vældig fint, at man har et godt samarbejde på videnskabsministerens område og at man tager en lang række initiativer, for det er meget vigtigt i den situation, vi står i globalt med hensyn til konkurrence osv. Det sætter vi ikke spørgsmålstegn ved.

Det, der er sagen, er, om regeringens ministre skal tage spørgsmålet om menneskerettigheder og demokrati op, når de er derovre. Ministeren så så undrende ud før, så jeg vil gerne præcisere, at der er tale om en artikel i Berlingske Tidende fra den 2. april, som har overskriften "Regeringen strammer Kina-kritikken", og hvor der står, at statsministeren siger, at ministrene som udgangspunkt skal udtrykke kritik, når de mødes med kinesiske kollegaer, og at fødevareminister Eva Kjer Hansen nu lover at kritisere på baggrund af det, der har været oppe den seneste tid.

Så det betyder vel, at statsministeren har været nødt til at gå ind og pointere over for fagministrene, herunder videnskabsministeren, at det altså er utrolig vigtigt, at spørgsmålet om menneskerettigheder og demokrati bliver rejst, når man rejser derover og i øvrigt har samarbejde på alle mulige områder.

\section{Videnskabsministeren:}

Det tror jeg, at jeg kan gøre her, for jeg bliver nødt til at sige til det, fru 
Kirsten Brosbøl citerer, om, at fagministrene skal udtrykke kritik, når de møder kinesiske kollegaer, at det lige akkurat er det, jeg har gjort som fagminister. Jeg har taget de tre områder $\mathrm{op}$, hvor der er problemer, og vi har påtalt det $\mathrm{og}$ fastholdt det $\mathrm{i}$ strategien. Så det synes jeg i og for sig at jeg har gjort, og det oplever ikke som nogen påtale, og hvis det er således, at der er en ændret politik i regeringen, så er det normalt noget, som vi ministre får besked på, og ikke noget, vi skal læse i en eller anden avis.

\section{Mogens Jensen (S),}

Ja tak, det var, fordi jeg nu hørte ministeren, som jo også har en fortid inden for sporten, sige, at man jo bedst påvirker ved ikke at sidde med armene over kors - jeg tror, det var sådan ministeren udtrykte sig - men ved at være til stede og ved at virke inden for sit felt, tror jeg også, ministeren fik sagt.

Der vil jeg bare høre, om jeg også skal forstå ministeren sådan, at ministeren klart mener, at det ikke hjælper noget at blive væk fra Kina eller boykotte Kina, men at man netop, som jeg hører ministeren sige, bliver nødt til at være til stede og udtrykke sin kritik i forhold til den almindelige virksomhed, som man nu har med kineserne, de muligheder, man har for at mødes med kineserne.

Var det sådan, jeg skulle forstå ministeren?

\section{Videnskabsministeren:}

Jeg vil gerne sige, uden at vi har drøftet disse forhold i regeringen, at jeg ikke bare mener, at det er på universitetsområdet, forskningsområdet eller på erhvervslivets område, at man skal være aktiv i forhold til Kina. Jeg mener absolut også, vi skal være det på idrætsbanen, og jeg vil være meget bedrøvet, hvis det er således, at Danmark ikke aktivt deltager på idrætsbanen under de forestående olympiske lege.

Men som sagt: Det er ikke mit ressort, vi har ikke drøftet det i regeringen, men det hænger selvfølgelig sammen med den overordnede holdning, jeg har til det at påvirke et land, hvor der i allerhøjeste grad er en række forhold, som ikke er, som de bør være.

\section{Mogens Jensen:}

Jeg synes, at det er meget klog tale fra ministeren. Man skal være der, man skal påvirke tingene, og det gælder sportsligt, det gælder på erhvervsområdet, og så går jeg ud fra, at ministeren også mener det på det politiske område.

\section{Videnskabsministeren:}

Ja, nu er det lige før, jeg siger: Desværre har jeg jo ikke ret meget med idrætten at gøre i relation til mit arbejde i regeringen. Så derfor er det jo ikke et forhold, jeg kommer til at skulle forholde mig til. Men jeg kan sige, at vi i regeringen overhovedet 
ikke har drøftet de her forhold, så jeg kan ikke sige noget om, hvordan og hvorledes de regeringsrepræsentanter, for hvem det måtte være relevant, vil forholde sig.

\section{Benny Engelbrecht:}

Det er selvfølgelig ærgerligt, at ministeren skal høre om regeringens politik igennem medierne. Men jeg kan da i hvert fald konstatere, at der i artiklen, som tidligere blev omtalt fra Berlingske Tidende den 2. april står et citat af hr. Anders Fogh Rasmussen, der lyder:

Udgangspunktet er, at når danske ministre møder kinesiske kollegaer, så føres der kritisk dialog om menneskerettigheder og demokrati.

Det er jo ikke første gang, at vi også fra vores side har måttet erfare regeringens politik igennem medierne - ikke engang nødvendigvis danske medier. Men det er en helt anden diskussion.
Mit spørgsmål skal derfor være, om ministeren som konklusion på dette punkt vil love i fremtiden at indgå i kritisk dialog med Kina. Det kan man nemlig godt være i tvivl om om man rent faktisk ønsker at være - på linje med ministerens kollega fru Eva Kjer Hansen.

\section{Videnskabsministeren:}

Hvis jeg hørte ret, tror jeg, det var det samme citat, som fru Kirsten Brosbøl kom med, så derfor er svaret akkurat det samme, som jeg har givet på et tidligere spørgsmål.

Men når det er sagt, vil jeg gerne tilføje, at jeg nok også fremover selv om jeg har den dybeste respekt for Berlingske Tidende - vil lægge mere vægt på det, der sker på regeringsmøderne, end det, jeg læser om regeringsmøderne i landets aviser.

Folketinget, 9. april 2008 